\title{
Penapisan antibakteri pada Bakteri Simbion Sinularia sp terhadap Escherichia coli
}

\author{
Ary Giri Dwi Kartika \\ Program Studi Ilmu Kelautan, Fakultas Pertanian, Universitas Trunojoyo Madura, \\ Email: ary.giridwi@gmail.com
}

\begin{abstract}
ABSTRAK
Beberapa studi yang telah dilakukan menunjukkan bahwa invertebrata (termasuk karang lunak) memiliki metabolit sekunder dengan konsentrasi yang rendah (10$6 \%$ dari berat basa invertebrata). Oleh karena itu dibutuhkan cara yang lebih konservatif dalam pemanfaatan metabolit sekunder untuk menjaga keseimbangan ekosistem.Tujuan dari penelitian ini adalah mengisolasi bakterisimbion Sinularia sp dan melakukan penapisan aktivitas antibakteri terhadap Escherichia coli. Isolasi bakteri simbion Sinularia sp dilakukan dengan menggunakan metode pengenceran dan sebar (spread). Purifikasi bakteri menggunakan metode streak, kemudian, uji antibakteri dilakukan dengan menggunakan metode overlay dan difusi agar. Sebanyak 5 isolat bakteri didapatkan dari hasil isoasi sampel. Hasil uji aktivitas antibakteri menunjukkan sebanyak 4 isolat (Isolat L2.2, L2.3, L2.4, dan L2.5) memiliki aktivitas antibakteri terhadap bakteri Escherichia coli. Isolat L2.5 memiliki diameter zona hambat terbesar yaitu sebesar 2,207 $\pm 0,401 \mathrm{~cm}$.
\end{abstract}

Kata Kunci: Sinularia sp, Antibakteri, Escherichia coli, Gili Labak.

Skrinning Antibacterial from Sinularia sp Symbiont Bacteria Againts Escherichia coli

\begin{abstract}
Several studies have shown that invertebrates (including soft corals) contain secondary metabolites in low concentration $(10-6 \%$ by wet weight of invertebrate). Therefore a more conservative approach is needed in the utilization of secondary metabolites to maintain the balance of ecosystems. The purposes of this study was to isolate the bacterium Sinularia sp and to screen antibacterial activity against Escherichia coli. Isolation of the bacteria symbione of Sinularia sp was performed by dilution method and spread. Purification of bacteria was performed by streak metho then, antibacterial test was done by using overlay method and agar disk-diffusion. A total of 5 bacterial isolates were obtained from the result of the isoation of the sample. The result of antibacterial activity test showed 4 isolates (Isolates L2.2, L2.3, L2.4, and L2.5) had antibacterial activity against Escherichia coli. Isolates L2.5 has the largest inhibitory zone diameter of $2.207 \pm 0.401 \mathrm{~cm}$.
\end{abstract}

Keywords: Sinularia sp, Antibactery, Escherichia coli, Gili Labak. 


\section{PENDAHULUAN}

Karang lunak termasuk kedalam filum Cnidaria, Kelas Anthozoa dan Subkelas Octocoralia. Alcyonacea adalah salah satu ordo dari filum Cnidaria yang terdiri dari ratusan jenis yang beragam dan salah satu diantaranya adalah jenis Sinularia $\mathrm{sp}$. Sinularia $\mathrm{sp}$ adalah salah satu karang lunak yang mendominasi tersebar di wilayah Indopasifik. Selanjutnya ditambahkan bahwa tingginya metabolit sekunder pada jaringan karang Lunak Alcyonacean berperan penting dalam keberhasilan evolusi organisme tersebut. (Sammarco and Coll, 1992).

Pemanfaatan invertebrata sebagai sumber senyawa bioaktif dapat mengancam ekosistem terumbu karang. Hal ini dikarenakan invertebrata (termasuk karang lunak) memiliki metabolit sekunder dengan konsentrasi yang rendah $\left(10^{-6} \%\right.$ dari berat basa invertebrata) (Prokosh et al, 2002). Oleh karena itu dibutuhkan cara yang lebih konservatif dalam pemanfaatan metabolit sekunder untuk menjaga keseimbangan ekosistem. Salah satunya adalah dengan memanfaatkan mikroorganisme yang bersimbiosis dengan invertebrata. Beberapa penelitian mengemukakan bahwa bahan alami bioaktif dari invertebrata laut sama persis dengan metabolit sekunder yang dihasilkan oleh mikroorganismenya termasuk bakteri. Oleh karena itu, pencarian metabolit sekunder dengan beranekaragam aktivitas dari bakteri simbion karang lunak menjadi bahan yang menarik untuk dikaji. Tujuan dari penelitian ini adalah mengisolasi bakterisimbion Sinularia sp dan melakukan penapisan aktivitas antibakteri terhadap Escherichia coli

\section{METODE PENELITIAN}

\section{Pengambilan Sampel}

Sampel Sinularia sp diambil pada kedalaman 7 - 11 meter menggunakan Scuba diving di Perairan Gili Labak, Kab. Sumenep. Sampel Sinularia $\mathrm{sp}$ selanjutnya dimasukkan ke dalam plastik zip lock, kemudian disimpan di dalam kontainer pendingin. selanjutnya sampel dibawa ke Laboratorium Bioteknologi Kelautan, Universitas Trunojoyo Madura guna dilakukan isolasi bakteri.

\section{Isolasi Bakteri}

Permukaan sampel Sinularia sp dibersikan dari pengotor dan organisme yang menempel dengan cara menyemprotkan air laut steril pada permukaan sampel. Sampel kemudian dihancurkan menggunakan mortar dan penumbuk steril, untuk selanjutnya dimasukkan ke dalam tabung reaksi berisi air laut steril sebanyak $9 \mathrm{~mL}$ dengan demikian didapatkan pengenceran $10^{\circ}$. Dari pengenceran $10^{\circ}$ tersebut diambil sebanyak $1 \mathrm{~mL}$ kemudian dimasukkan ke dalam tabung berisi $9 \mathrm{~mL}$ air laut steril sehingga didapatkan pengenceran $10^{-1}$. Demikian selanjutnya dilakukan didapatkan pengenceran $10^{-5}$. Sebanyak $100 \mu \mathrm{L}$ dari masingmasing seri pengenceran $10^{-3}, 10^{-4}$ dan $10^{-5}$ disebar di atas media agar half strength zobell 2216E, kemudian diinkubasi selama 48 jam pada suhu kamar (Benson, 2002). Pemurnian bakteri dilakukan dengan mengggunakan metode gores. 


\begin{abstract}
Penapisan Aktivitas Antibakteri
Uji pendahuluan aktivitas antibakteri dilakukan dengan menggunakan metode over lay (Sabdono dan Radjasa, 2006). Setiap satu ose bakteri simbion Sinularia sp ditanam pada media ZoBell 2216E laut (dalam satu cawan petri ditanam 5 - 12 titik bakteri) dan dibentuk menjadi bulatan kecil. Kemudian cawan petri diinkubasi pada suhu kamar selama 2 hari. Sedangkan isolat bakteri $E$. coli ditanam pada media cair Zobell 2216E kemudian digojog menggunakan rotary shaker selama 2x24 jam. Suspensi bakteri E. coli diambil $1 \mathrm{~mL}$ ( $1 \%$ dari total volume soft agar) dan dimasukkan ke dalam $100 \mathrm{~mL}$ media Zobell 2216E soft agar.
\end{abstract}

Selanjutnya media Zobell 2216E soft agar tersebut dituang ke dalam cawan petri yang berisi biakan bakteri simbion Sinularia sp yang sudah diinkubasi 2 hari sebelumnya, kemudian diinkubasi pada suhu ruang selama 1-2 hari dan diamati perkembangannya. Isolat bakteri simbion karang yang aktif akan menghambat bakteri $E$ coli dan akan terlihat dengan terbentuknya zona bening (hambat). penapisan aktivitas antibakteri dilakukan dengan menggunakan metode difusi agar (Radjasa et al, 2007). Sebanyak $100 \mu \mathrm{L}$ bakteri $E$. coli pada fase log (109 sel/mL) disebar diatas media agar zobell 2216E. Sepuluh kertas cakram (6mm; Advantec, Toyo Roshi, Ltd, Jepang) yang telah terkandung bakteri simbion Sinularia $\mathrm{sp}$, diletakan pada permukaan media agar zobell 2216E yang sebelumnya telah disebar bakteri E. coli. Cawan petri kemudian diinkubasi pada suhu kamar selama 48 jam. aktivitas antibakteri ditunjukkan dengan adanya zona hambat (clear zone) disekitar kertas cakram.

\section{HASIL DAN PEMBAHASAN}

\section{Isolasi Bakteri}

Sebanyak 10 isolat bakteri didapatkan dari hasil isolasi Sinularia sp. kesepuluh isolat tersebut memiliki kenampakan morfologi koloni yang berbeda-beda. Kenampakan morfologi koloni bakteri diamati berdasarkan warna, bentuk, elevasi dan margin (Waluyo, 2012). Waluyo (2012) menyatakan bahwa bentuk koloni bakteri yang telah diisolasi dari lingkungannya akan berbeda tiap spesiesnya, serta memiliki ciri tersendiri yang membedakannya dengan spesies lain. Selanjutnya ditambahkan oleh Lay (1994) yang menyatakan bahwa pengamatan tentang karakteristik morfologi koloni bakteri perlu dilakukan, agar mempermudah dalam proses identifikasi jenis bakteri. Tabel mengenai morfologi koloni bakteri simbion Sinularia $\mathrm{sp}$ tersaji pada tabel 1.

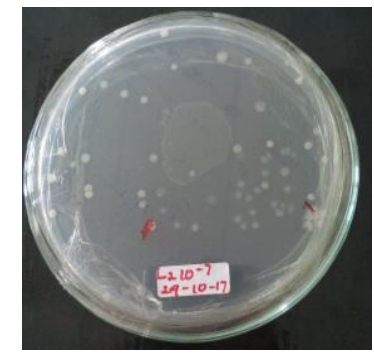

Gambar 1. Koloni Bakteri Simbion Sinularia sp yang telah diisolasi 
Tabel 1. Karakteristik Morfologi Koloni Bakteri Simbion Sinularia sp

\begin{tabular}{ccllll}
\hline No. & Kode & \multicolumn{1}{c}{ Warna } & \multicolumn{1}{c}{ Bentuk } & \multicolumn{1}{c}{ Margin } & \multicolumn{1}{c}{ Elevasi } \\
\hline 1 & L2.1 & Putih Bening & Tidak beraturan & Berbelah & Timbul Datar \\
2 & L2.2 & Kuning & Bulat & Utuh & Rata \\
3 & L2.3 & Putih Kekuningan & Bulat & Utuh & Timbul Datar \\
4 & L2.4 & Kuning & Bulat & Utuh & Timbul Datar \\
5 & L2.5 & Putih Susu & Berbenang & Berbenang & Timbul Datar \\
\hline
\end{tabular}

Sumber: Data Primer, 2017

Tabel 2. Hasil Uji Aktivitas Antibakteri dari Bakteri Simbion Sinularia sp

\begin{tabular}{ccc}
\hline No. & Kode Isolat & Aktivitas Antibakteri \\
\hline 1 & L2.1 & - \\
2 & L2.2 & + \\
3 & L2.3 & + \\
4 & L2.4 & + \\
5 & L2.5 & + \\
\hline
\end{tabular}

Sumber: Data Primer, 2017

Tabel 3. Hasil Uji Difusi Agar

\begin{tabular}{ccc}
\hline No. & Kode Isolat & Diameter Zona Hambat $(\mathrm{cm})$ \\
\hline 1 & L2.2 & $0,743 \pm 0,111$ \\
2 & L2.3 & $1,643 \pm 0,006$ \\
3 & L2.4 & $1,370 \pm 0,128$ \\
4 & L2.5 & $2,207 \pm 0,401$ \\
\hline
\end{tabular}

\section{Penapisan Aktivitas Antibakteri}

Hasil uji overlay menunjukkan dari 5 isolat bakteri simbion Sinularia sp terdapat 4 isloat bakteri yang menunjukkan aktivitas antibakteri $E$. coli. Hal ini ditunjukkan dengan adanya zona hambat (clear zone) disekitar bakteri simbion Sinularia sp. hasil uji overlay disajikan pada tabel 2 .

Penapisan uji aktivitas antibakteri dilakukan menggunakan metode difusi agar dengan kertas cakram. Hasil uji difusi agar menunjukkan isolat L2.2, L2.3, L2.4 dan L2.5 mampu menghambat pertumbuhan E.coli. Hal ini ditunjukan dengan terbentuknya zona hambat (clear zone) disekitar kertas cakram. Dari keempat isolat tersebut, isolat L2.5 memiliki diameter zona hambat terbesar yaitu
$2,207 \pm 0,401 \mathrm{~cm}$. Penghambatan pertumbuhan bakteri disebabkan oleh beberapa faktor, salah satunya yaitu terjadinya kompetisi antara bakteri siombion Sinularia sp dengan E. coli untuk mendapatkan ruang dan nutrisi yang digunakan untuk pertumbuhan (Teasdale, 2009; Iqbal, 2014). Selain itu, penghambatan pertumbuhan juga dipengaruhi oleh adanya sistem pengeluaran metabolit sekunder dalam bentuk enzim eksternal atau eksoenzim yang berasal dari sel bakteri simbion karang.

Barrios-Gonzalez et al. (2003) menyatakan bahwa produksi metabolit sekunder oleh suatu organisme dilakukan ketika nutrien utama tidak tersedia atau tersedia dengan terbatas. 
Sehingga metabolit sekunder yang diproduksi adalah sebagai respon dari lingkungan. Metabolit sekunder memiliki fungsi sebagai pertahanan diri, mencegah terjadinya infeksi, media interaksi serta media dalam proses reproduksi (Faulker et al, 2000). Data mengenai hasil uji difusi agar disajikan pada tabel 3.

\section{DAFTAR PUSTAKA}

Barrios-Gonzalez.2003. Secondary

Microbial

Production Metabolites Improvement Indian Journal of Biotechnology, 2:322-333

Benson H J. 2002. Microbiological Applications A Laboratory Manual in General Microbiology 8th Edition. New York: The McGraw-Hill Companies

Faulkner, D. J., M.K. Harper, M.G. Haygood, C.F. Salomon, E.W. Schmidt. 2000. Symbiotic Bacteria in Sponge: Source of Bioactive Substance. In: Fusetani, N. (Ed). Drugs from the Sea, 107-119.

lqbal, J. R. Siddiqui, N. A. Khan. 2014. Acanthamoeba and Bacteria Produce Antimicrobials to Target Their Counterpart. Parasites \& Vector, 7:56.

Lay, B. W. 1994. Analisis Mikroba di Laboratorium. PT RajaGrafindo Persada, Jakarta.155 hlm.

Proksch, P., R.A. Edrada, and R Ebel. 2002. Drugs from the Seas Current Status and Microbiological Implications. Appl. Microbiol. Biotechnol. 59: 125-134.

\section{SIMPULAN}

Bakteri simbion Sinularia sp yang didapatkan dari isolasi adalah sejumlah 5 isolat bakteri yang terdiri dari isolat L2.1, L2.2, L2.3, L2.4, dan L2.5. Hasil uji antibakteri didapatkan 4 isolat (L2.2, L2.3, L2.4, dan L2.5) bakteri simbion Sinularia sp menunjukkan aktivitas antibakteri Es. coli. Isolat L2.5 menunjukkan diameter zona hambat terbesar yaitu sebesar $2,207 \pm 0,401$ $\mathrm{cm}$.

Radjasa O. K, A. Sabdono, Junaidi and E. Zocchi. Richness of secondary metabolite-producing marine bacteria associated with Sponge Haliclona sp.. Int. J. Pharmacol. 2007.3(3):275-9.

Sabdono, A \& Radjasa, O. K. 2006. Anti-Bacterial Property of A Coral-Associated Bacterium Bacillus sp Against coral Pathogenic BBD (Black Band Disease). Journal of Coastal Development, 9:175-182.

Sammarco, P.W. and J. C. Coll 1990. Lack of predictability in terpenoid function: Multiple roles and integration with related adaption in soft corals. J. Chem. Ecol. (16) 1: 273-289.

Teasdale, M. E., J. Liu, J. Wallace, F. Akhlaghi, D. C. Rowley. 2009. Secondary Metabolites Produced by the Marine Bacterium Halobacillus salinus That Inhibit Quorum Sensing-Controlled Phenotypes in Gram-Negative Bacteria. Appl. Environ. Microbiol., 75 (3): 567-572.

Waluyo, L. 2012. Mikrobiologi Umum. UMM Press, Malang, 344. 